\title{
A Review of the Development of the Integration Strategy of Information Technology and Education in the Four Countries of the United States, Britain, China, and Singapore
}

\author{
Jincheng Wang \\ Epson (China) Co. Ltd, No.81, Beijing 100025, China
}

\begin{abstract}
Information technology has a revolutionary impact on the development of education. Therefore, it is a strategic choice to comprehensively respond to educational development challenges in the information age to promote the modernization of education with education informatization. Countries worldwide have begun to attach importance to the development of educational information technology and have successively formulated a series of policies and plan to guide its development. At the same time, implementing a number of measures has dramatically promoted the realization of educational information technology development goals. Taking the United States, Britain, China, and Singapore as examples, we reviewed the promotion strategies of global education informatization and summarized its typical characteristics and development trends based on an overview of the development routes of various countries.
\end{abstract}

Science Insights Education Frontiers 2021; 9(2):1283-1303.

Doi: $10.15354 /$ sief.21.re042

How to Cite: Wang, J. (2021). A Review of the development of the integration strategy of information technology and education in the four countries of the United States, Britain, China, and Singapore. Science Insights Education Frontiers, 9(2):1283-1303.

Keywords: Informatization of Education, Development Strategy, United States, Britain, Singapore, China 
Wang. Integration Strategy of Information Technology and Education.

Correspondence to: Jincheng Wang, Epson (China) Co. Ltd, No.81, Jianguo Road, Chaoyang District, Beijing 100025, China. E-mail: wang.jincheng@ecc.epson.com.cn

Conflict of Interests: None.

(C) 2021 Insights Publisher. All rights reserved.

(c) (i) (8) Creative Commons Non Commercial CC BY-NC: This article is distributed under the terms of the Creative Commons Attribution-NonCommercial 4.0 License (http://www.creativecommons.org/licenses/by$\mathrm{nc} / 4.0 /$ ) which permits non-commercial use, reproduction and distribution of the work without further permission provided the original work is attributed by the Insights Publisher. 


\section{Introduction}

7 HE term "informatization" first appeared in some academic documents in Japan in the 1960s. At that time, the concept of "informatization" was mainly elaborated and defined from an industrial perspective. In the 1970s, Germany, the European Union, and UNESCO issued a series of plans to promote the application and development of information technology in society. These plans all regard information infrastructure as an essential part.

In September 1993, the Clinton administration of the United States formally proposed the construction of the "National Information Infrastructure" (NII), commonly known as the "Information Superhighway" plan. The core is to develop a comprehensive information service system centered on the Internet and promote the broad application of Information Technology (I.T.) in various fields (Clinton White House, 1993). Driven by this, many developed and developing countries have successfully issued a series of national information infrastructure construction plans, leading to a wave of global informatization construction.

The concept of education informatization was put forward with the construction of the information superhighway in the 1990s. In the U.S. "Information Superhighway" plan, the application of I.T. in education is mainly regarded as an important way to implement educational reforms oriented to the 21 st century. This move by the United States has aroused positive reactions from all countries in the world. Developed countries represented by Britain and Singapore have successively formulated plans to promote the application of I.T. in education in their countries. In addition, developing countries represented by China have also begun to pay attention to education informatization and gradually incorporate education informatization into their national development strategies.

With the rapid development and innovation of information technology and its continuous penetration into education, the importance of education informatization in education reform and development has become increasingly prominent. Governments of various countries have successively formulated strategic plans at the national level to guide the development direction of education informatization. At the same time, a series of measures have been taken to promote the concrete implementation of education informatization policies, which in turn fosters education reform and innovation. The policy of educational informatization embodies the overall thinking and basic direction of the country's development of educational informatization. It has a macro-planning and guiding role for its construction and development and is an essential guarantee for the effective development of educational information technology activities.

This article selects the United States, Britain, and Singapore as developed countries, and China as a developing country, and summarizes the development of education informatization in the four countries. First, outline the three stages of the development of global education informatization and then research the promotion path of international education informatization policy. It is helpful to deeply understand the current situation and product rules of education informatization in developed and devel- 
oping countries to provide a valuable reference for the in-depth promotion of the development of global education information.

\section{Global Educational Information Technology Devel- opment Process}

The accelerated development of modern information technology in the 1990s promoted education informatization in all countries worldwide. As an actual content and indicator of cross-century education reform, the education informatization has been included in the new round of education reform plans worldwide. Various policy plans have been issued one after another. Under the guidance of the policy, a phased and gradual strategy has been adopted to promote the development of educational information. Due to the differences in economic and social development, the stages of educational informatization development in different countries in the same period are different. To meet the needs of different stages of development, the focus of education information policies formulated by various countries will continue to evolve and change. But on the whole, its strategic development route has major phase characteristics. It can be divided into the following three stages:

\section{Information Infrastructure Comprehensive Construc- tion Stage}

Education informatization includes many aspects, including infrastructure construction, information resource construction, teacher informatization training, and policies and regulations. Infrastructure construction refers to constructing campus networks, multimedia classrooms, learning terminals, and other hardware environments. The primary content of educational information is infrastructure construction (Jiao et al., 2014), which plays an essential supporting role in developing and applying educational information.

In September 1993, the United States proposed the National Information Infrastructure (NII) strategy, aiming to build a highway in the information age based on the Internet. In the "National Educational Technology Action Plan" promulgated in early 1996, it is clearly stated that each classroom needs to have a computer that can connect to the Internet, high-quality learning software, and well-trained teachers (NETP1996) (U.S. Office of Educational Technology, 1996). In 1998, the U.S. government invested 51 billion U.S. dollars in enabling every U.S. citizen to use information technology for lifelong learning. The survey showed that in 1994, only $3 \%$ of schools in the United States were connected to the Internet; in 1996, $4 \%$ of schools could meet the requirement of 1 computer for every five students, and $9 \%$ of classrooms could be connected to the Internet (Glennan \& Melmed, 1996); In 1999, this figure had reached 63\%; in 2000 , it was refreshed to more than $90 \%$. 
Britain also pays special attention to the development of information infrastructure in ICT education. At this stage, the government vigorously supports the construction of educational information infrastructure from policies and funds. In 1998, the British government promulgated "Our Information Age" demanding that the government reform education, use new technologies in education, and use the government's investment in education funds. As a result, a total of $6 \%$ of education funds were used for school hardware purchases, ensuring that $20 \%$ of Britain's elementary and middle schools could connect to the Internet. This policy directly promoted the large-scale construction of Britain's educational infrastructure. According to the statistics provided by Ofsted in 2004, the proportion of schools with digital projectors nationwide was $80 \%$ for elementary schools and 99\% for middle schools (Ofsted, 2004).

Singapore is one of the earliest countries in the development of global education information. In 1997, the Ministry of Education promulgated a five-year basic education informatization development plan-Masterplan 1 (MP1). The implementation of MP1 has laid a solid foundation for integrating information technology and curriculum in schools. In particular, it has played a significant role in providing Information Communications Technology (ICT) infrastructure and enabling teachers to have a basic level of ICT integration capabilities. The implementation of MP1 has achieved good results. By the end of MP1, all schools were equipped with ICT infrastructure to support teaching, connected to the Internet, and directly accessed the Ministry of Education website. The student-to-computer ratio in elementary schools was 6.6:1, and in middle schools was 5:1 (Lyu, 2016).

China's education informatization construction is a little later than that of developed countries. In 1998, the Ministry of Education formulated the "Action Plan for the Promotion of Education in the 21st Century". It implemented the modern distance education project (MOE, 1998). In 1999, the Central Government and the State Council issued the "Decision on Deepening Education Reform and Comprehensively Promoting Quality Education," which clearly stated that "we must vigorously improve the modernization of educational technology and the level of educational informatization" (Government of the People's Republic of China, 1999). In 2000, the Ministry of Education issued the "Notice on the Implementation of the School-to-School Connection Project in Primary and Secondary Schools," which became the first national development plan in education informatization in China (Ministry of Education of China, 2002). In 2001, the State Council issued the "Decision on the Reform and Development of Basic Education" (No. Guo Fa [2012]), which began to pay attention to information construction in rural areas and other areas with weak education, and in 2003 began to implement the modern distance education project for rural primary and secondary schools (Government of the People's Republic of China, 2001). This series of policies paved the way for the construction of educational information technology.

Since 2000, China Education Satellite Broadband Multimedia Transmission Network (CEB-sat) and China Education and Research Computer Network (CERNET) have been established one after another. As a result, the rate of access to the Internet and China's educational satellite broadband has increased substantially in schools at all 
levels. In 2012, to meet the needs of the development of education in the new era, the "Three Links and Two Platforms" widely carried out nationwide (Zhang, 2019).

As the first step in advancing educational information, the main task is to achieve the initial coverage of educational networks and campus networks and form a digital resource service system. In terms of a specific time, most information infrastructure construction in developed countries such as the United States, Britain, and Singapore began in the 1990s. The complete construction of the infrastructure was completed at the beginning of the 21 st century. Due to different levels of development, developing countries represented by China started relatively late (most of them started in the early 21 st century), but from the perspective of the development stage, the first stage of their development was led by the complete construction of information infrastructure.

\section{Popularization and Application Stage}

With the overall advancement of infrastructure construction, applying information technology to education has become the focus of attention of all countries. Especially in the case of a mismatch between technical literacy and facility building, popularizing the application of information technology in education is the focus of this stage.

U.S. information infrastructure construction has made remarkable achievements in the first phase. On the contrary, it is the challenge of the low technical literacy of the whole people. Schools in most areas do not use information technology for teaching (Zhu et al., 2014).

In this context, the U.S. government has successively issued national education technology plans, which involve infrastructure construction, information resource construction, and teacher information literacy. Starting from the second plan launched in 2000, the program's focus shifted to improving teachers' information literacy. At the same time, the promulgation of the No Child Left Behind Act of 2001 once again emphasized that we must not only invest in hardware construction but also strengthen teacher training and integrate infrastructure construction and applications. Therefore, in the third national educational technology plan, seven action plans are proposed: strengthen leadership; consider reform budgets; improve teacher training; support digital learning and virtual schools; encourage the use of broadband networks; move toward digital content; establish integrated information system (U.S. Department of Education, Office of Educational Technology, 2004). In the development plan of NETP2000 and NETP2004, the United States focuses on promoting digital resources and professional development of teachers, paying attention to the construction of digital resources that meet the individualized learning of students, and improving teaching applications through teacher training.

In the first phase of Singapore's 1997 development plan MP1, they were promoting the promotion of teachers, and students' information literacy has been listed as one of the goals. Therefore, after completing the first phase of the plan, the information literacy of teachers and students has been dramatically improved: teachers have mas- 
tered the essential ability of information technology and curriculum integration, and students have acquired the necessary skills to complete ICT-based projects or tasks. Based on the first phase of the plan, in 2003, the Ministry of Education of Singapore launched the second phase of the 5-year basic education informatization development plan-Masterplan 2 (MP2). Compared with MP1, which focused on school information technology infrastructure construction, MP2 concentrated on the deeper application of information technology in education (Lyu, 2016). In 2005, Singapore implemented the I.T. Demonstration School Project. The project selected $15 \%$ of schools as pilot projects, encouraged them to apply information technology in teaching, formed a typical information technology teaching application model, and actively promoted it nationwide.

The same was true in Britain. The information strategy of Harnessing Technology: Transforming Learning and Children's Services was released in 2005. It proposed to make full use of ICT technology in various fields of education and children's services to provide complete service environment support for learners' personalized learning. Harnessing Technology: Next Generation Learning, which started in 2008, more clearly proposed to use ICT to provide learners with learning tools, online support, customizable resources, and technical guidance to promote learners' personalized learning (Becta, 2008; Laurillard, 2005).

After the first phase of comprehensive information infrastructure deployment, China quickly shifted the construction task to application popularization. In March 2012, the Ministry of Education issued the "Ten-Year Development Plan for Education Informatization (2011-2020)" (hereinafter referred to as the "Ten-Year Plan"). As a result, the overall design and nationwide deployment of education informatization work for the next ten years has been carried out from the national level-China's first longterm strategic plan for education information (MOE, 2013).

The "Ten-Year Plan" proposed to make education informatization a strategic focus and priority area for national information development. By 2020, an informationbased learning environment in which everyone can enjoy high-quality educational resources will be established, an information-based support service system for a learning society will be formed, and the broadband network of all regions and schools at all levels will be formed fully covered. In addition, education management information will be achieved. As a result, the level of integration and development of information technology and education has improved significantly. In May 2015, China's first International Education Informatization Conference was held in Qingdao, Shandong. In the meeting, the goal of "building a networked, digitized, individualized, and lifelong education system" was set up. Building a learning society where everyone learns, can learn everywhere, and can learn at all times. Cultivate a large number of innovative talents." It is pointed out that it is necessary to "expand the coverage of high-quality educational resources employing informatization" and promote educational equity through educational informatization (Li \& Lyu, 2015). In June 2016, the Ministry of Education issued the "Thirteenth Five-Year Plan for Education Informatization." It mainly embodies three concepts: the first was from construction to application, the second was from a single point to the overall situation, and the third was from a line to integration (MOE, 
2016). The official release of the "Ten Year Plan" and the convening of the first national education informatization conference have enabled China's education informatization work to develop rapidly. Data showed that in 2015, the school's online teaching environment dramatically improved. The Internet access rate of elementary and middle schools in China was $83 \%$. The penetration rate of multimedia classrooms was $73 \%$; high-quality digital education resources were becoming more abundant, and information-based teaching was becoming more popular (Zhao, 2015).

At this stage, digital education resources are widely shared, and information technology is commonly used in education and teaching. In this process, paying attention to educators' information literacy and building extensive and rich digital education resources have become the strategic priorities of all countries. However, the focus of construction differs between countries. For example, Singapore assigns a "peopleoriented" value to technology and focuses on cultivating digital learners. On the other hand, the United States believes that teachers are operators who truly integrate information technology and education, and therefore pay more attention to the professional training of teacher information.

\section{Integration and Innovation Stage}

After the first two rounds of development, the level of education informatization in various countries has been improved to a certain extent. However, different countries have put forward new requirements for students' knowledge and ability structure to encourage students to adapt to the information age. Therefore, various countries have gradually shifted their development focus from hardware facilities to information technology to promote education reform and innovation and teach to cultivate innovative talents that meet social development needs.

First of all, in the United States, although the level of educational information in the United States has improved significantly after more than ten years of development, the two problems of the low graduation rate of college students and significant differences in academic achievement between students have not been resolved. To solve these two problems, in 2009, former U.S. President Barack Obama put forward the goal of "the graduation rate of American colleges and universities should regain the leading position in the world by 2020." And in 2010, The National Education Technology Plan, Transforming American Education: Learning Powered by Technology (U.S. Department of Education, Office of Education Technology, 2010), was promulgated. The plan put forward goals and suggestions in five areas: learning, evaluation, teaching, infrastructure, and productivity, and hope to build a lifelong learning system that continues to develop through technology. In November 2015, the Office of Educational Technology of the U.S. Department of Education issued the fifth "U.S. Educational Technology Plan"-Future Ready Learning: Reimagining the Role of Technology in Education (NETP2016). The plan re-examined the role of technological change learning, aimed to narrow the long-standing gap in fairness and accessibility through changes in learning 
methods and experiences, and created conditions for the development of all learners (U.S. Department of Education, Office of Education Technology, 2015).

Britain's educational informatization development has always had its characteristics. After going through the stage of popularization and application, such as infrastructure construction and ICT course construction, Britain began to focus on cultivating students' innovative qualities. In March 2016, Britain released the DfE Strategy 2015 to 2020: World-Class Education and Care. They formulated the education development strategy and plan for the next five years. They proposed vigorously promoting the opening rate of STEM courses and improving the quality of related classes (U.K. Department for Education, 2016).

The same is true in Singapore. To further promote the development of education informatization, the Ministry of Education of Singapore formulated the three-phase development plan for basic education informatization-Masterplan 3 (MP3) in 2009. Based on continuing to advance the vision of MP1 and MP2, MP3 further promotes the application of ICT in the teaching process, thereby cultivating students' collaborative learning and autonomous learning capabilities (Lyu, 2016). In 2015, the Ministry of Education of Singapore formulated the fourth basic education informatization development plan - Masterplan 4 (MP4) (Lyu, 2016). MP4 broadens the focus of attention throughout the course. It not only focuses on independent learning and collaborative learning but also focuses on quality learning and cultivates future-oriented and responsible digital learners and citizens. In the MP4 strategy, ICT is continuously integrated into courses, teaching methods, subject evaluation, and learning resources so that technology can be better integrated into the learning field. At the same time, MP4 adopts a more systematic assessment of various ICT capacities building work and emphasizes the social transformation of research.

After the 1.0 stage of education informatization characterized by "infrastructure + equipment supporting + application exploration," China's education informatization has entered the 2.0 stage. Education informatization 2.0 is to open a new era of integrated innovation and intelligent leadership based on the "three links and two platforms" of the 1.0 stage. In April 2018, the Ministry of Education of China issued the Education Informatization 2.0 Action Plan, which proposed to achieve the development goal of "Three Completions, Two Improvements and One Big Platform" by 2022. That is, the teaching application covers all teachers; the learning application covers all school-age students; the construction of digital campus covers all schools; the level of information application is improved; the information literacy of teachers and students is improved, and a large "Internet + education" platform is built. Furthermore, to create a new model of talent training under the conditions of "Internet + ," develop a new model of Internetbased education services and explore a new model of education governance in the information age (MOE, 2018).

As the third stage of the development of education informatization, all countries have placed innovation and integration in a strategic position. At this stage, the close integration of information technology and education has become the theme of development. The cultivation of students' future-oriented quality is highly valued. In 
addition to the quality of informatization teaching, humanistic care has become a new trend of development.

\section{The Promotion Path of Education Informatization in Various Countries}

The four countries have also achieved impressive results in facility construction, resource development, team training, and application enhancement from a horizontal perspective. This has provided strong support for the reform of teaching and laid a foundation for reshaping educational forms. Although the educational reform tasks faced by various countries in different historical stages are different, the policies implemented are also other in connotation and extension. However, from the perspective of the deepening of education reform and facing the challenges of human society in the 21 st century, there are some commonalities. These commonalities are embodied in the characteristics and measures presented in educational information technology construction in various countries worldwide.

\section{Pay Attention to Infrastructure Construction and Appli- cation}

The construction of educational informatization infrastructure was the foundation for the development of educational informatization and a prerequisite for supporting the development of educational informatization (Liu et al., 2013). Therefore, in the education informatization strategic plans formulated at different stages of development, all countries attached great importance to the construction of infrastructure. Moreover, with the continuous development and advancement of technology, countries' goals for infrastructure construction were also constantly improving.

From the explanation in the second part of this article, it can also be seen that all countries have put education infrastructure construction first. Under the operational guidance of the government, countries continue to increase investment in the construction of information infrastructure. According to statistics from the U.S. White House, from 2013 to 2015, even in the mid-term of the development of information technology, the U.S. investment in information infrastructure continued to grow. In 2015, only $\$ 4.7$ USD billion was invested in purchasing high-speed networks and personal ICT equipment. In Britain, the investment and construction of ICT infrastructure is also the main content of the government's attention. Britain added 160 million pounds to the 2012 science and education budget to construct information infrastructure to help universities share massive research data more efficiently. In January 2016, the Minister of Education Nicky Morgan announced that the British government would invest 130 million pounds in improving the current network infrastructure, aiming to provide all students with an online learning environment anytime and anywhere (Community Editorial Team at Comcast Business, 2017; Matthews, 2013; Morgan, 2016). 
From the perspective of the specific content of the construction, due to the different national conditions and educational status quo, there are also distinct differences among countries. China emphasized the overall improvement of the allocation level of school campus networks, multimedia classrooms, and subject teaching resource tools and promoted the sharing of high-quality digital education resources. The United States not only regarded computers and the Internet as an essential part of infrastructure construction but also regarded personnel and learning resources as part of comprehensive learning infrastructure. Singapore emphasizes the student-to-computer ratio, teacher-tocomputer ratio, and Internet coverage (Zhu et al., 2014).

\section{Attach Importance to Digital Education Resource Ser- vices}

In addition to infrastructure construction, the advancement of education informatization is inseparable from the development and application of digital education resources. Therefore, at the same time as infrastructure construction, the four countries have gradually formed a mechanism for the service and operation of digital education resources from construction, application to evaluation after long-term development (Sun \& Liu, 2016).

In Britain's educational information development process, a notable feature is the construction of educational resources. Based on ensuring infrastructure construction, Britain puts resource construction in a strategic position for its development. It provides strong support from the capital to the workforce to ensure the smooth development of its basic education informatization. The Britain National Learning Network, launched in January 1998, is an online education resource channel provided by the British government. It is also a significant information highway education channel. It makes full use of the network to connect schools, research institutions, and libraries to establish a unified education network and education services. It is a national information network system for developing and applying online learning, teaching, and public services. Britain's national learning network is rich in teaching resources, including teacher training, education research, teacher professional development, education consulting, education supervision, library, employment consulting and training, vocational education, education management, and other extensive information resource columns. Currently, Britain's National Learning Network has become the most comprehensive education portal in Europe. It has a robust search function, with a total of about 250,000 index pages. What's more noteworthy is that its resources are still developing, and new websites are still being added. It will create an increasingly rich and diversified resource environment for Britain education.

Although the United States was not a pioneer in constructing digital resources, it had a far-reaching influence on digital education resources. In April 2001, the Massachusetts Institute of Technology in the United States began to implement OpenCourseWare (OCW) with the core concept of co-construction and sharing of educational resources and freely open the teaching materials created by the school. In 2003, 
the OCW website was officially launched. Under the permission of free re-use, learners can use the MIT courses freely and openly through the website, including syllabus, lecture notes, assignments, and core teaching materials for examinations. At present, OCW has released more than 2,500 MIT courses, attracting more than 200 million learners from all over the world and inspiring the global open learning movement. Thus, the world connects users worldwide through information technology to acquire cuttingedge knowledge (OpenCourseWare, 2021).

Driven by OCW and the Open Educational Resource Movement, in 2012, a new type of open education model, Massive Open Online Courses (MOOCs), was born. As soon as MOOCs were proposed, they were highly praised by users all over the world. Typical MOOCs platforms include Coursera, Udacity, and edX. There are thousands of online courses open on these platforms, with millions of learner users. They set up course types according to different majors and certify students' course learning in credits and certificates. Driven by world-renowned universities and commercial capital, the rapid rise of MOOCs worldwide has promoted globalization, democratization, and fairness of higher education (Pappano, 2012).

The construction of educational resources in China started relatively late. In 2003, the Ministry of Education of China proposed establishing the school, provincial, and national three-level quality courses in various disciplines and majors. It aims to provide learners with a curriculum resource system that supports lifelong learning (MOE, 2003). In 2012, it proposed to build a public service platform for educational resources, aiming to realize the co-construction and sharing of resources (Hao \& Xiong, 2012). In 2014, "One Teacher, One Excellent Class; One Class, One Master Teacher" was launched. As of July 2021, the platform has received 16.97 million lessons from teachers across the country (MOE, 2021). In addition, as MOOCs entered the Chinese education vision in 2013, China's online open courses have developed rapidly. Currently, there are hundreds of platforms related to MOOCs. For example, platforms such as NetEase Cloud Classroom, School Online, China University MOOC, and Chinese MOOC have been launched one after another, gathering a wealth of learning resources and a large number of learners. As of the end of January 2020, there were 3,166 courses taught on the MOOC platform of Chinese universities alone (China University MOOC, 2021).

\section{Using Technology as a Means to Realize the Reform of Teaching and Learning}

The core goal of the development and practice of educational informatization is to promote the transformation of learning and teaching, which is fully reflected in the change of learning and teaching methods by information technology.

To improve the quality and efficiency of student learning and realize the full development of individual students, various countries have put forward new requirements on student learning methods and learning support systems. For example, the United States NETP2010 put forward the " 21 st-century learning model supported by 
technology", emphasizing the use of ICT to create a learning atmosphere, provide practical tools and enrich learning resources so that learners can entirely freely choose learning methods. NETP2016 was based on the fundamental goal of cultivating participatory and autonomous learning supported by ICT. It designed a "learning framework that is ready for the future" and emphasized creating a ubiquitous learning environment to form new participatory learning and autonomous learning supported by information technology.

Britain released its Harnessing Technology: Transforming Learning and Children's Services strategy in 2005. It proposed using ICT to carry out a comprehensive educational information transformation to promote teaching reforms and provide teaching environment support for personalized learning students. The "Next-Generation Learning" movement that began in 2008 also clearly proposed using ICT to provide learners with learning tools, online support, customizable resources, and technical guidance to promote learners' personalized learning (Becta, 2008). In the DfE Strategy 2015 to 2020: World-Class Education and Care released in 2016, the principle of "children and young people first" was clearly defined. It emphasized that "quality everywhere" education should be learner-centered, and the student-centered education model would continue to be deepened and implemented (U.K. Department for Education, 2016).

Singapore had popularized a new teaching model in which teachers used information technology to create a student-centered learning environment in MP2. MP3 emphasized that teachers design learning content in an information environment promote students' independent and collaborative learning. MP4 required teachers to become the designers of student learning experience and background in the information technology environment and provided ubiquitous and personalized teaching (Tang et al., 2016).

The relevant texts of China's education information policy also emphasize promoting the integrated development of information technology and education. Expand from serving teaching to serving educating people, and build new learner-centered education ecology. It can be seen that the use of information technology to transform learning and teaching methods and to innovate curriculum content and teaching methods has become the consensus of the promotion of educational information technology in China and abroad.

\section{Pay Attention to the Professional Development of Teachers}

The four countries have put forward new teachers' abilities and roles to promote information technology and curriculum integration. New Media Consortium Horizon Report: 2014 Basic Education Edition pointed out that "reshaping the role of teachers" is a crucial factor in applying educational technology in schools in the next one to two years (Johnson et al., 2014). With the rapid development of information technology and its gradual application in education and teaching, teachers were expected to be able to skillfully use information technology and other methods to improve their work, such as 
the delivery of teaching content, the evaluation of students' academic performance, the cooperation between teachers, and the daily work of the school. Therefore, training teachers' professional skills, especially applying information technology, was a meaningful way to promote capacity development.

Since NETP1996, the United States has paid attention to teachers' ICT application capacity building. NETP2000 proposed that all teachers should have the ability to use technology to promote students' high-level learning effectively. Each subsequent plan emphasized the requirements and cultivation of teachers' ICT application ability. In NETP2016-2017, based on emphasizing the increase of teachers' connection ability, the provision of changing the role of teachers was put forward. It clarified that teachers should be the guide, facilitators, motivators, and co-learner of student learning. Schools and specialized institutions should provide teachers with continuous and timely support and guarantee information technology capacity training, professional development, and informal collaboration.

In 1997, the British government established the Virtual Teacher Center (VTC) website. It provided teachers with a large number of online resources and trains teachers on the skills, knowledge, and concepts of information technology teaching (Jung, 2005). The American Educational Resources Portal (GEM) provided teachers with specific software and resource training to encourage them to make full use of digital education resources to help to teach (Jobe, 2010). In addition, by setting up awards for teachers, teachers are encouraged to use digital resources in teaching. For example, the British government has specially set up the British Educational Training and Technology Show to promote teachers' digital education resources. In 1998, the Initial Teacher Training National Curriculum in ICT Use in Subject Teaching was promulgated. It put forward requirements for teachers' ICT skills. In 2004, the Secretary of State for Education and Skills of Britain launched a hands-on support project to improve teachers' ability to integrate ICT and teaching (BETT, 2021; Rizza, 2011; Secretary of State for Education and Skills, 2004).

Singapore has emphasized the training of teachers' ICT skills from MP1 and clearly stated that teachers should have the ability to integrate ICT and curriculum and teach informatization. Both MP2 and MP3 continued and strengthened this requirement. MP4 required teachers to become designers of students' learning experience and environment based on the role of learning partners.

In China, the construction and development of the teaching staff have been the critical content of the education information policy since 2010. Teachers' informatization training and development measures were also abundant. Such as implementing the teacher information technology application ability improvement project, the formulation and improvement of teacher education technology ability training curriculum standards, and the organization of "One Teacher, One Excellent Class; One Class, One Master Teacher " activities, etc. The "Education Informationization 2.0 Action Plan" launched the "Artificial Intelligence +" teacher team building activities, and the "Opinions on the Implementation of the National Elementary and Middle School Teachers' Information Technology Application Ability Improvement Project 2.0" 
officially launched the Information Technology Application Ability Improvement Project 2.0. It promoted teachers to actively adapt to new technological changes such as informatization and artificial intelligence and actively and effectively carry out education and teaching in the intelligent era (Wang, 2019).

\section{Conclusions and Perspective}

While implementing educational informatization in the four countries, we can see some trends in the development of global education informatization, try to outline these trends, and summarize the characteristics of global education informatization in the emerging stage.

\section{Four Countries Have Put the Development of Educa- tion Informatization in a Strategic Position}

Since the 21 st century, governments worldwide have regarded the priority development of educational information as an essential factor related to their country's international competitiveness and development prospects in the 21 st century. Accordingly, they have formulated education informatization policies and adopted a series of actions. To ensure national education informatization planning continuity, governments worldwide attach importance to top-level design and solve practical problems faced by education informatization in a phased and progressive manner.

Corresponding to this is the information industry. Judging from the development experience of various countries, enterprises in the information industry field have played a positive role in the development of education informatization in multiple countries. The construction of educational informatization infrastructure, innovative software and hardware research and development, and the research on core technologies of educational informatization have all been supported by related enterprises in the information industry.

With the rapid development of the current information industry, the demand in the education information field presents diversified characteristics. Therefore, to ensure that education-oriented enterprises can support the development of this field for a long time, governments of various countries have also given corresponding designs in terms of policies and investment models, which are conducive to its sustainable development.

\section{The Development of Education Informatization Has Promoted the Innovation of Education}

Promoting educational reform is the value orientation of global education informatization; that is, the fundamental purpose of educational informatization is to promote the overall reform of education so that education can meet the requirements of the information age for talent training goals, training models, educational organization management models, and service models. In the infrastructure construction stage, the 
rapid development of information technology has promoted the emergence of various innovative products and changes in application methods, bringing new technologies and concepts into classroom teaching. The introduction of new technologies such as cloud computing, 3D printing, wearable, augmented reality, games, and gamification into the classroom has wholly affected students' learning styles and teachers' teaching styles. Open concepts such as available courses, open data, open resources, open education, open access, and open thinking have real value in applying information technology in education. In addition, social networks and social media are changing the way people live and communicate, as well as the form of knowledge acquisition.

In addition, with the rapid development of makerspace, wearable technology, adaptive learning technology, etc., and their widespread application in education, future educational trends such as blended learning, open educational resources, and interschool cooperation have become increasingly prominent. More and more schools and teachers have begun to pay attention to the individual needs of students. These new educational concepts will substantially impact teachers' technology and pedagogical knowledge when gradually introduced into classroom teaching. They will promote indepth changes in teachers' teaching methods and students' learning methods. Especially during the COVID-19 pandemic, countries have used Internet technology to carry out online teaching. Online teaching, which is separated from school education, has triggered an upgrade of the classroom teaching model to a greater extent. Some studies have shown that the pandemic outbreak has led to a massive change in the teaching model (Cheng et al., 2020).

\section{Educational Equity Has Become the Strategic Focus of Education Informatization in Developing Countries}

Educational equity issues exist at different levels in the development process of education in various countries. There are specific differences in the level of educational development between regions, races, and nationalities. Especially with the development of informatization, the digital gap characterized by the ability to obtain information is expanding. The Global Information Technology Report 2015 pointed out that "the digital gap between countries is expanding," which will exacerbate the "global learning crisis" (Dutta et al., 2015). The digital gap refers to the unbalanced performance of specialized hardware and software resources. Still, it is also reflected in the gap in the individual's ability to obtain information and behavioral awareness. As a result, as the digital gap between countries in the world expands, the power of citizens to get information will also grow.

To respond to the possible Global Learning Crisis and promote education equity, the U.S. government has prioritized developing remote and backward rural areas. Special attention will be paid to education policies for particular groups, and education informatization policies will be implemented in economically underdeveloped areas to help poverty-stricken areas and rural schools to cross the digital gap. The E-Strategy Strategic Plan of the British government proposes to provide national broadband ser- 
vices to all institutions, especially the development of ICT infrastructure and services for disadvantaged groups (Office for National Statistics, 2021). Invest in technology for students in a dire economic situation so that ordinary students or students with disabilities in these schools can use the same advanced technology. Due to national conditions and other reasons, in the development of basic education informatization, China particularly emphasizes narrowing the gap in infrastructure and digital resources between the east and the west and between urban and rural areas. It also requires a number of measures to support the development of basic education informatization in economically underdeveloped regions.

Therefore, ensuring that every child can receive high-quality education has become the focus of educational development in all world regions. However, the Global Learning Crisis is still emerging. Even in developed countries and areas with a high level of economic growth and a good level of information technology, the teaching mode supported by the technological environment does not fully reflect the learnercentered approach. A large proportion of various teaching models are still teachercentered. Only by reducing the digital gap and strengthening the learning design in the technological environment can the situation of the Global Learning Crisis be further improved.

The exchanges between different cultures and economies brought about by globalization make people face the critical role of education in communication, cooperation, and competition. Moreover, educational technology and reforms under different social conditions and backgrounds are integrated with different degrees and methods. Therefore, when researching education models and education development, it is necessary to understand the development trends of various countries from a higher level. And it is essential to face the growth of global education to take care of the reality of education in the country and strive to achieve the integration of internationalization and localization of education.

\section{Notes}

1. "Three links and two platforms" refer to broadband network school-school links, high-quality resources, class-to-class links, and network learning spaces for everyone; construction of a public service platform for educational resources and a public service platform for education management. 


\section{References}

Becta. (2008, July 3). Harnessing Technology: Next Generation Learning 2008-14. BEC115571. Retrieved July 05, 2021 from https://webarchive.nationalarchives.gov.uk/2 0101105142034/http://publications.becta.org .uk $/$ display.cfm?cfid $=6535338 \&$ cftoken $=\mathrm{d} 0$ 934f4999ceb5f3-1C58B17A-AF25-CF32063F0819A13AF983\&resID $=37348 \&$ page $=$ $\underline{1835}$

BETT. (Last accessed July 28, 2021). British Educational Training and Technology Show. Have Group. https://www.bettshow.com/

Cheng, X., Pellegrini, M., Zhou, L., \& Cheung, A. C. K. (2020). Not Only Survival but Stronger: The Impact of Alarming Invader of SARS-CoV-2 on Global Education. Science Insights Education Frontiers, 7(2):835860. DOI:

https://doi.org/10.15354/sief.20.or061

Chinese University MOOC. (Last accessed July 28, 2021). About icourse. Retrieved July 10, 2021 from https://www.icourse163.org/ [Chinese]

Clinton White House. (1993, September 15). The National Information Infrastructure: Agenda for Action. The National Archives and Records Administration. Retrieved July 15,2021 from

https://clintonwhitehouse6.archives.gov/199 3/09/1993-09-15-the-national-informationinfrastructure-agenda-for-action.html

Community Editorial Team at Comcast Business. (2017, February 07). Technology in Education: Elevating the Learning Experience. Comcast Corporation. Comcast Business. Retrieved July 10, 2021 from https://business.comcast.com/community/br owse-all/details/technology-in-educationelevating-the-learning-experience\# ftn 4

Dutta, S., Geiger, T., \& Lanvin, B. (2015, April 01). Global Information Technology Report 2015. World Economic Forum. Retrieved July 10, 2021, from http://www3.weforum.org/docs/WEF_GITR 2015.pdf

Glennan, T.K., \& Melmed, A. (1996). Fostering the use of educational technology: Elements of a national strategy. Santa Monica, CA:
RAND Corporation. DOI:

https://doi.org/10.7249/MR682

Government of the People's Republic of China. (1999,June 13) The decision of the Central Committee and the State Council on deepening education reform and comprehensively promoting quality education. Retrieved July 02, 2021, from

http://www.moe.gov.cn/jyb_sizl/moe_177/tn ull_2478.html [Chinese]

Government of the People's Republic of China.(2001, May 29). Decision of the state council on the reform and development of basic education. Retrieved July 02, 2021, from

http://www.gov.cn/gongbao/content/2001/co ntent 60920.htm [Chinese]

Hao, M., \& Xiong, X. (2012, December 28). National education resources public service platform opened. Retrieved July 05, 2021, from

http://edu.people.com.cn/n/2012/1228/c1053 -20049241.html [Chinese]

Jiao, J., Jia, Y., \& Ren, G. (2014). Research on macro-policy and strategy of educational informationization. Journal of Distance Education, 32(01): 25-32. [Chinese] DOI: https://doi.org/10.15881/j.cnki.cn331304/g4.2014.01.007

Jobe, H. (2010, May 07). The Gateway to Educational Materials (GEM). Education World. Retrieved July 15, 2021, from https://www.educationworld.com/awards/pa st/r0599-06.shtml

Johnson, L., Becker, S. A., Estrada, V., \& Freeman, A. (2014). NMC horizon report: 2014 K (pp. 1-52). The New Media Consortium.

Jung, I. (2005). ICT-pedagogy integration in teacher training: Application cases worldwide. Journal of Educational Technology \& Society, 8(2):94-101.

https://www.jstor.org/stable/jeductechsoci.8. 2.94

Laurillard, D. (2005). Harnessing technology: Transforming learning and children's services. The open archive HAL, hal-00190344. https://telearn.archives-ouvertes.fr/hal00190344/document 
Li, G., \& Lyu, Y. (2015). 2015 The international education information conference was held in Qingdao, Shandong. Journal of World Education, 28(12):2. [Chinese] http://www.cnki.com.cn/Article/CJFDTotalJYXI201512001.htm

Liu, Y., Ren, G., Li, C., \& Wu, J. (2013). Constructing advanced network infrastructure to support the development and application of education informatization. Bulletin of Chinese Academy of Sciences, 28(4):482-490. [Chinese]

http://www.cnki.com.cn/Article/CJFDTotalKYYX201304009.htm

Lu, C. (2016) Singapore's basic education informatization development strategy and its enlightenment. Journal of World Education, 29(13):10-15.

https://d.wanfangdata.com.cn/periodical/sijy xx201613003

Matthews, D. (2013, November 22). Business enterprise research and development, U.K.: 2012. Office for National Statistics. Retrieved July 10, 2021 from

https://www.ons.gov.uk/economy/governme ntpublicsectorandtaxes/researchanddevelop mentexpenditure/bulletins/businessenterprise researchanddevelopment/2013-11-22

Morgan, N. (2016, January 20). Nicky Morgan: the benefits of technology in education. GOV.UK. Retrieved July 10, 2021, from https://www.gov.uk/government/speeches/ni cky-morgan-bett-show-2016

Office for National Statistics. (2021, February 05). E-commerce and ICT Activity 2019. GOV.UK. Retrieved July 05, 2021, from https://www.gov.uk/government/statistics/ecommerce-and-ict-activity-2019

Office for Standards in Education, Ofsted. (2004, May). ICT in schools: The impact of government initiatives five years on. Ofsted Publications Centre. Retrieved July 15, 2021 , from https://dera.ioe.ac.uk//6461/

OpenCourseWare. (Last Accessed July 28, 2021). About OCW. MIT OpenCourseWare. https://ocw.mit.edu/about/

Pappano, L. (2012, November 2). The Year of the MOOC. The New York Times. Retrieved July 10, 2021, from https://www.nytimes.com/2012/11/04/educat ion/edlife/massive-open-online-courses-aremultiplying-at-a-rapid-pace.html

Rizza, C. (2011). ICT and Initial Teacher Education: National Policies. OECD Education Working Papers, No. 61, OECD Publishing. DOI:

http://dx.doi.org/10.1787/5kg57kji5hs8-en

Secretary of State for Education and Skills. (2004). Department for Education and Skills: Five Year Strategy for Children and Learners. HM Government. Retrieved July 10, 2021 from

https://dera.ioe.ac.uk/4886/7/DfES5 Yearstrat egy_Redacted.pdf

Sun, C., \& Liu, H. (2016,). Digital education resource configuration mode transformationfrom the co-construction and sharing to the public to be shared. 2016 Eighth International Conference on Measuring Technology and Mechatronics Automation (ICMTMA). IEEE. DOI:

https://doi.org/10.1109/ICMTMA.2016.64

Tang, X., Yan, Z., Yuan, J., \& Fu, J. (2016). Review of Singapore's new educational Informatization strategy-Based on master plan 4. Modern Educational Technology, 26(11): 27-32. [Chinese] http://qikan.cqvip.com/Qikan/Article/Detail? id $=670633724$

The Ministry of Education of the People's Republic of China (MOE). (1998, December 24) The Ministry of Education's Action Plan for the Promotion of Education in the 21st Century Retrieved July 02, 2021, from http://www.moe.gov.cn/jyb_sizl/moe_177/tn ull 2487.html [Chinese]

The Ministry of Education of the People's Republic of China (MOE) . (2002, March 27) Notice the Ministry of Education on implementing the "School-to-School Link" project in elementary and middle schools. Retrieved July 02, 2021, from

http://www.edu.cn/jiaoyu_xinxi/zhong_da_x iang_mu/xiao_xiao_tong/tong_zhi_gong_ga o/200603/t20060323_25903.shtml [Chinese]

The Ministry of Education of the People's Republic of China (MOE). (2016, June 7). Notice of the ministry of education on printing and distributing the "Thirteenth FiveYear Plan for Education Informatization". 
Retrieved July 04, 2021, from

http://www.moe.gov.cn/srcsite/A16/s3342/2 01606/t20160622_269367.html [Chinese]

The Ministry of Education of the People's Republic of China (MOE). (Last accessed July 28, 2021). National Education Resources Public Service Platform.

https://1s1k.eduyun.cn/portal/html/1s1k/inde $\mathrm{x} / 1$.html\# [Chinese]

The Ministry of Education of the People's Republic of China (MOE). (2003, April 8). Notice of the Ministry of Education on Starting the Construction of Excellent Courses for Teaching Quality and Teaching Reform Projects in Higher Education Institutions. Retrieved July 04, 2021, from

http://www.moe.gov.cn/s78/A08/gjs_left/s56 64/moe 1623/s3843/201010/t20101018 109 658.html [Chinese]

The Ministry of Education of the People's Republic of China (MOE). (2013). Critical Points of Education Informatization in 2013. The Chinese Journal of ICT in Education, 19(7):3-5. [Chinese]

http://www.cnki.com.cn/Article/CJFDTotalJYXX201307001.htm

The Ministry of Education of the People's Republic of China (MOE). (2018, April 18). Notice of the ministry of education on issuing the "education informatization 2.0 action plan”. Retrieved July 04, 2021, from http://www.moe.gov.cn/srcsite/A16/s3342/2 01804/t20180425 334188.html [Chinese]

U.K. Department for Education. (2016). DfE strategy 2015 to 2020: World-class education and care. Retrieved July 04, 2021, from https://www.gov.uk/government/publication s/dfe-strategy-2015-to-2020-world-classeducation-and-care

U.K. Department for Education. (2016, March

17). DfE strategy 2015 to 2020: world-class education and care. GOV.UK. Retrieved July 15,2021 , from

https://assets.publishing.service.gov.uk/gove rnment/uploads/system/uploads/attachment data/file/508421/DfE-strategy-narrative.pdf

U.S. Department of Education, Office of Education 'Technology. (2015) . Future Ready Learning: Reimagining the Role of Technology in Education. National Educational
Technology Plan2016. Retrieved July 04, 2021, from https://tech.ed.gov/netp/

U.S. Department of Education, Office of Education Technology. (2010). Transforming American education: Learning powered by technology. National Education Technology Plan 2010. Retrieved July 04, 2021, from http://tech.ed.gov/wpcontent/uploads/2013/10/netp2010.pdf

U.S. Department of Education, Office of Educational Technology. (2004). Toward a new golden age in American education: How the Internet, the law, and today's students are revolutionizing expectations. National Education Technology Plan 2004. Retrieved July 05, 2021, from

https://files.eric.ed.gov/fulltext/ED484046.p df

U.S. Office of Educational Technology. (1996). Getting America's Students Ready for the 21st Century: Meeting the Technology Literacy Challenge: A Report to the Nation on Technology and Education. US Department of Education.

Wang, J. (2019, April 03). The ministry of education of China issued the "Opinions on the Implementation of the national elementary and middle school teachers' information technology application ability improvement project 2.0" to establish a new teacher information literacy development mechanism. Retrieved July 05, 2021, from China Education News

http://www.moe.gov.cn/jyb_xwfb/s5147/201 904/t20190403_376571.html [Chinese]

Zhang, W. (2019). With a flick of your finger, China's education informatization has changed dramatically for 70 years. China Education Network, 16(10): 7-10.[Chinese] http://kns.cnki.net/KCMS/detail/detail.aspx? dbcode $=$ CJFD \&filename $=J Y W L 201910005$

Zhao, X. (2015, May 16). China's education informatization has made six breakthroughs in three years. Retrieved July 04, 2021, from http://www.moe.gov.cn/jyb_xwfb/s5147/201 505/t20150516 188211.html

Zhu, S., Zhang, Y., Yang, H., \& Wu, D. (2014). A comparative study of China and the United States in the development of new basic education informatization strategies. Open 
Wang. Integration Strategy of Information Technology and Education.

Education Research, 20(2):34-45. [Chinese] DOI: https://doi.org/10.13966/j.cnki.kfjyyj.2014.0 2.007

Received: 13 August 2021

Revised: 03 August 2021

Accepted: 27 July 2021 